\title{
ИСТОРИЧЕСКИЕ, ПОЛИТИЧЕСКИЕ И ПРАВОВЫЕ ФАКТОРЫ ЭКОНОМИЧЕСКОЙ ИНТЕГРАЦИИ СТРАН ЕВРОПЫ И АМЕРИКИ: РЕТРОСПЕКТИВА И СОВРЕМЕННОСТЬ
}

\begin{abstract}
Аннотация. В настоящей статье рассматриваются исторические, политические и правовые факторы экономической интеграции стран Европы и Америки в такие объединения как ЕС, НАФТА и МЕРКОСУР. В ретроспективе автор исследует и анализирует идеи, предпосылки и основные вехи развития объединительной стратегии на Американской континенте и в Европе; автор также анализирует тенденции современности. Внимание также уделяется взаимодействию ЕС, НАФТА и МЕРКОСУР друг с другом и с другими результатами объединительной стратегии (ЛАИ, АЛКА, АЛКАС и др.). Цель исследования состоит в выявлении закономерностей развития интеграционных процессов в Америке и Европе. Методы исследования, используемые автором, сравнительно-правовой, исторический, диалектический, специально-научные методы. Методология исследования - представление об объективно-субъективной заданности любых процессов. Сделанный обзор интеграционных процессов на Американском континенте и в Европе, показывает, что в процессе интеграции рассмотренных стран прослеживается ряд закономерностей.
\end{abstract}

Ключевые слова: политология, сравнительное, правоведение, интеграция, Европа, Американский , континент, ЕС, НАФТА, МЕРКОСУР.

В настоящее время интеграция рассматривается как объединение материальных, организационных, финансовых, трудовых, интеллектуальных ресурсов отдельных стран для совместного решения проблем, связанных с их функционированием и развитием ${ }^{1}$. В экономическом смысле этапы и уровни интеграции разделяются на последовательное образование зоны таможенных преференций, зоны свободной торговли, таможенного союза, общего рынка, экономического и валютного союза, полной экономической интеграции ${ }^{2}$.

Естественно, формы объединения стран существенно зависят от преследуемых целей, начиная от увеличения торговых потоков, получения политической силы и возможности для переговоров, до интеграции в целях развития с учетом географического характера, начиная от приграничной или двухсторонней до региональной или субрегиональной․․ Интеграция выражается в таком объединении суверенных государств, в котором могут свободно циркулировать различные факторы производства, внешними прояв-

Бахин С.В. Понятие и механизмы международно-правового сближения правовых систем // Российский ежегодник международного права / Российская ассоциация международного права; ред. кол.: Л.Н. Галенская (гл. ред.) и др. СПб.: СКФ «Россия - Нева», 2001. С. 64.

2 Экономика: учебник / под ред. А.И. Архипова, А.Н. Нестеренко, А.К. Большакова. М.: «ПРОСПЕКТ», 1999. С. 448-460.

3 Напр.: Капустин А.Я. Международно-правовые проблемы латиноамериканской экономической интеграции: учеб. пособие. М.: Изд-во УДН, 1986. лениями которого являются: образование единых товарных рынков; создание общего рынка средств производства (товаров, услуг, рабочей силы капиталов); проведение согласованной внешней политики ${ }^{4}$.

Ясно, что экономическая интеграция не будет проявляться, если государства-участники этого процесса не будут вносить соответствующие изменения в свои правопорядки. Именно целенаправленное изменение правопорядка и отличает интеграцию от простого экономического сотрудничества. Поэтому с юридической точки зрения интеграцию, вероятно, следует определить «как процесс целенаправленного внесения изменений в правопорядки государств, участвующих в процессе интеграции, с целью их гармонизации и унификации в определенных областях» ${ }^{5}$.

\section{1. Панъевропейская идея}

И дея объединения Европы возникла задолго до идеи экономической интеграции ${ }^{6}$ и высказывалась европейскими мыслителями,

\footnotetext{
4 Комаров А.С., Бардина М.П., Шумилов В.М. Международное экономическое право: учеб.-методич. пособие. М.: ДЕКА-ВС, Государственный центральный музей музыкальной культуры им. М.И. Глинки, 1999. С. 148.

5 Калачян К. Региональная экономическая интеграция как часть мирового процесса интеграции. М.: МАКС-Пресс, 2003. С. 35.

6 Подробнее о понятии, содержании и теориях региональной экономической интеграции см.: Ложечко М.С. Странычлены НАФТА и интеграционные процессы (проблемы и перспективы): дис. ... канд. экон. наук. М., 2000. С. 9-23.
} 


\section{Региональные конфигурации международных отношений / Regional configuration of international relations}

учеными и политическими деятелями на протяжении многих веков. Она базировалась на вере в существование закона, стоящего превыше права высшей политической власти. Этот закон называли когдато божественным правом, потом естественным правом, а позже - правами человека.

С середины XI в. все страны Запада входили в область римской католической церкви, существовали при одной системе церковного права 7 . Это право, основанное на религиозных идеях справедливости, нашло отражение в jus commune - романо-каноническом праве, одинаковом для всех европейских народов $^{8}$. В тот же период была создана совокупность сословных светских правовых норм, регулировавших транснациональную торговлю на ярмарках, регулярно проводимых по всей Европе ${ }^{9}$, и наблюдалось крупномасштабное возрождение древнегреческой философии и римского права, восполнявшего недостатки в появившемся светском законодательстве ${ }^{10}$. Таким образом, у народов Западной Европы, имевших самые тесные интеллектуальные, культурные и политические связи друг с другом, оставшиеся, в значительной мере, от Римской Империи, возникла социо-культурная идентичность и правовая общность, основанная на каноническом и римском праве, а также праве торговцев. Среди объединительных проектов того времени можно назвать предложение французского юриста П. Дюбуа в 1306 г. создать в Европе «Христианскую республику».

Зарождение в XVI в. новых реформаторских вероучений, противопоставляемых католицизму кальвинизма, протестантизма, лютеранства - нарушило общность религиозных представлений народов Европы, а после образования в Европе национальных государств, когда каждая нация пристально следила за поведением своих подданных и тщательно оберегала собственный суверенитет, право рассматривалось как национальный феномен и превратилось в выражение этого суверените-

\footnotetext{
Берман Г. Дж. Западная традиция права: эпоха формирования / Пер. с англ. 2-е изд. М.: Изд-во МГУ: Издательская группа ИНФРА-М-НОРМА, 1998. С. 34.

8 Вилкова Н.Г. Договорное право в международном обороте. М.: «Статут», 2002. С. 18; Cruz P. A Modern Approach to Comparative Law. P. 335-336. Цит. по: Казачкова 3.M. Государственное антимонопольное регулирование в России и США: сравнительно-правовое исследование: дис. ... д-ра юрид. наук. М., 2002. С. 98-99.

9 Берман Г. Дж. Цит. соч. С. 320-334.

10 Аннерс Э. История европейского права (пер. со швед.) / Ин-т Европы. М.: Наука, 1994. С. 175-178; Берман Г.Дж. Цит. соч. С. 31, 261-280.
}

та ${ }^{11}$. Однако возникшая религиозная и национальная разобщенность не привела европейцев к утрате правового единства, базировавшегося на римском праве, представлявшем важную общую черту права различных европейских стран, и рационалистическом естественном праве ${ }^{12}$. 0 сохранении духовного единства свидетельствует тот факт, что в этот период многочисленные проекты относительно устройства «единой Европы» высказывались представителями различных государств (Англия 1639 г. герцог Сюлли, 1693 г. - У. Пенн; Германия 1795 г. И. Кант; Франция - 1814 г. А. Сен-Симон; Швейцария - 1878 г. И.К. Блюнчли $)^{13}$. В начале XX в. стал популярен проект создания Соединенных Штатов Европы (СШЕ) по образцу американского федерализма. Эти проекты, имевшие ярко выраженный политический и военный характер, возникали как реакция на кровопролитные конфликты, столкновения и противостояния в Европе либо за утверждение господства той или иной страны на континенте (Тридцатилетняя война, Первая и Вторая мировые войны), либо от внешнего противника (Османская империя, Российская империя, СССР).

\section{2. Панамериканская идея}

Идея объединения Америки - панамериканская - также возникла задолго до идеи экономической интеграции и впервые была сформулирована в период антиколониального движения в Латинской Америке (1810-1830 г.) президентом первого независимого после колонизации государства на американском континенте - США - Дж. Монро в 1823 г. в виде императива внешней политики США «Америка для американцев» - декларации защиты своих соседей от новой колонизации любой европейской державой в интересах США.

К этому времени на территориях испанских и португальских колоний за трехсотлетний период колонизации (конец XV - начало XIX вв.) сформировался новый тип народонаселения - латиноамериканцы - потомки коренного населения, африканцев и европейцев, приверженные католической вере. Социально-экономическое своеобразие Латинской Америки было обусловлено скорее

\footnotetext{
11 Монтескье Ш. О духе законов. Кн. 1. Гл. ІІІ // Монтескье Ш. Избранные произведения. М.: Гос. изд-во политич. литературы, 1995. С. 168.

12 Аннерс Э. Цит. соч. С. 218.

13 Право Европейского Союза: учебник для вузов / под ред. С.Ю. Кашкина. М.: Юристъ, 2002. С. 54-62; Топорнин Б.Н. Европейское право: учебник. М.: Юристъ, 2001. С. 33-35.
} 


\section{Международные отношения International Relations}

длительностью колонизации и природно-климатическими и социально-демографическими особенностями территорий, нежели различиями между колонизаторами (Испании и Португалии), находившимися в тот период на стадии становления и развития монархической формы правления. Управление колониями базировалось на колониальном праве, противоречивом и запутанном, поскольку развивалось из феодального сословного испанского и португальского, которое само находилось на стадии интеграции римского и канонического права. В результате - практически вся колониальная администрация саботировала исполнение нежелательных для себя законодательств, а на уровне правосознания и правоприменения укоренился юридический «формализм» - разрыв между устанавливаемым законодательством и реально складывающимся правопорядком ${ }^{14}$.

Колонизация остальной части Североамериканского континента, планомерно осуществлявшаяся англичанами и французами с XVII в., завершилась победой Англии в 1763 г. в семилетней борьбе с Францией, что предопределило путь развития региона. С одной стороны, Декларация независимости 1776 г. объединила 13 английских колоний в длительной (1775-1783 г.) борьбе с митрополией за новое государство США, начавшее с начала XIX в. стремительно расширять свою территорию в соответствии с доктриной Дж. Монро от побережья Атлантики на запад, юг и север за счет территории соседей (коренных жителей, мексиканцев, русских), что сформировало новую общность народонаселения страны - американцев. С другой стороны, остальные (северные) английские колонии, присоединившие к себе французские, только в 1867 г. были преобразованы в самоуправляющийся британский доминион Канада, который получил от английского правительства самостоятельность во внутренней и внешней политике лишь в 1931 г.

Однако, хотя пути развития государственности британских колоний Северной Америки разошлись в последней четверти XVIII в., изначально управляемые согласно одному правовому мировоззрению и приверженности естественному праву они сохранили общность культурных традиций, религии и языка.

14 Безбах В.В., Беликова К.М. Что заставляет латиноамериканцев объединяться? Образование Южноамериканского Общего рынка и его развитие // Внешнеторговое право. 2006. № 1(6). С. 8-12; Жидков О.А. Становление правовых систем в странах Латинской Америки // Государственно-правовые проблемы стран Латинской Америки. Сб. научных трудов. М.: Изд-во УДН, 1988. С. 6-31.
Торговое противостояние Великобритании и США, возникшее вследствие обретения последними независимости, привело в первой половине XIX в.: со стороны бывшей митрополии - к необходимости отказа от протекционистской защиты внутреннего рынка и перехода к свободной торговле под давлением, в основном, американских частных корпораций; со стороны США - к расширению торговли с Канадой на основании Договора взаимности, подписанного в 1854 г. и просуществовавшего 12 лет, и формированию после гражданской войны 1861-1865 г. между северными и южными штатами страны единого общенационального рынка в целях развития экономики страны.

Учитывая, что к началу XIX в. специфика развития экономики Американского континента, особенно латиноамериканских территорий, заключалась в достижении мировых масштабов объема производства экспортной продукции и разделения труда при одновременной слабой развитости сектора, направленного на удовлетворение первоочередных нужд населения, США потребовалось почти столетие для осознания необходимости развития собственной экономики.

В отличие от США в странах Латинской Америки экономическая верхушка социальной пирамиды, не разрушенной в процессе освободительного движения, добившись свободы действий на мировом рынке, приветствовала и способствовала проникновению на материк на волне антииспанизма английского, французского и американского капиталов. В результате - развитие промышленности, обслуживающей внутренний рынок государств, оказалось подавлено потоком европейских товаров, что вынудило правительства обратиться к иностранным займам, поэтому в конце XIX в. иностранному капиталу на территории всей Латинской Америки удалось осуществить новую форму зависимости - экономическую ${ }^{15}$.

В этой ситуации президентом США Олни в 1895 г. была сформулирована новая доктрина - «Америка для североамериканцев» - декларировавшая суверенную власть США на американском континенте, предназначенная для сдерживания европейских капиталов и предопределявшая Латинской Америке роль вассала, интересы которого на международ-

15 Так, например, в конце XIX в. почти четверть национальных богатств Аргентины, включая землю, принадлежала иностранцам, в основном, англичанам; а ее долг Англии к 1880 г. составлял 20 млн фунтов стерлингов. См.: Безбах В.В., Беликова К.М. Что заставляет латиноамериканцев объединяться? Образование Южноамериканского Общего рынка и его развитие // Внешнеторговое право. 2006. № 1(6). С. 8-12. 


\section{Региональные конфигурации международных отношений /}

Regional configuration of international relations

ной арене должны выражать и защищать США. С этого момента развитие стран Латинской Америки продолжалось не только в зависимости от действий иностранного капитала, но и при политическом вмешательстве США. С помощью экономического давления и военной силы США навязали многим латиноамериканским республикам договоры, которые грубо нарушали их суверенитет, ${ }^{16}$ но на все попытки Канады возобновить Договор взаимности отвечали отказом. Важным инструментом политики США в Америке стали проводимые с 1899 г. Панамериканские конференции и образованный в 1910 г. Панамериканский союз.

\section{3. Развитие объединительных идей в Европе и Америке: образование ЕС, МЕРКОСУР И НАФТА}

Объединительные идеи в Европе и Америке возникали как ответная реакция на социально-политические преобразования в этих регионах: в Америке - в виде панамериканской доктрины в период антиколониального движения (1810-1830 гг.); в Европе - в виде проекта образования Соединенных Штатов Европы, обсуждавшегося в период после первой мировой войны и образования государства с новой социалистической идеологией СССР (1917-1924 г). Изначально эти идеи носили охранительный характер для обоих регионов против экспансии: европейских государств - на американский континент; Советской идеологии - в европейские страны.

B XX в. объединительные процессы стали развиваться практически одновременно в Европе и в Америке.

В Европе в 1921 г. между Бельгией и Люксембургом было заключено двустороннее соглашение об экономическом союзе, предусматривавшее координацию внутренней и внешней экономической политики двух государств. В 1944 г. к ним присоединились Нидерланды, после чего был образован тройственный таможенный союз стран Бенилюкса.

На американском континенте США осуществили экономическое сближение с Канадой и военнополитическое - со странами Латинской Америки. В 1935 г. было подписано первое (после разрыва в 1866 г. Договора о взаимности и получения Канадой

\footnotetext{
16 Примером может служить договор Хея-Бюно-Варильи (el Tratado Hay-Bunau-Varilla), по которому США получали «на вечные времена» право на строительство и эксплуатацию Панамского канала, неограниченный контроль над полосой земли через перешеек шириной 10 миль и право вмешательства во внутренние дела государства.
}

политической самостоятельности в 1931 г.) канадоамериканское соглашение о предоставлении США и Канадой друг другу режима наибольшего благоприятствования, и в 1938 г. - второе - о взаимном снижении таможенных пошлин на целый ряд изделий. Новое качество двусторонним отношениям было придано после заявления президента США Ф. Рузвельта в 1938 г. о том, что США готовы и будут защищать территорию Канады от нападения или возможного вторжения в такой степени, в какой это потребуется для защиты территории США. В Латинской Америке в 1933 г. США и 20 латиноамериканских стран подписали Пакт Монтевидео о правах и обязанностях государств, провозгласивший невмешательство последних в дела друг друга.

Вторая мировая война явилась новым мощным стимулом для развития двусторонних отношений США и Канады в сфере производства и обмена оборонными и стратегическими материалами и оборудованием и для консолидации стран Америки в военно-политический союз на основе договора о взаимопомощи, закрепившего принцип «континентальной солидарности».

Огденсбургская декларация декларация (1940 г.) оформила военно-политическое сотрудничество США и Канады и положила начало «особым» отношениям между странами, а Гайд-паркское соглашение о развитии экономических связей (1941 г.) явилось началом экономической интеграции экономик обеих стран, спецификой которой была зависимость Канады от США ${ }^{17}$. Договор о взаимопомощи привел к учреждению в 1948 г. Организации американских государств (ОАГ).

В Европе практические действия по объединению были возобновлены после окончания второй мировой войны знаменитой речью, произнесенной 5 марта 1946 г. У. Черчиллем в Фултоне ${ }^{18}$. В ней западноевропейские страны призывались к провозглашению в них принципов свободы и демократии, нашедших свое самое знаменитое выражение в Декларации Независимости США 1776 г., с целью защиты народов этих государств от тирании полицей-

\footnotetext{
17 Вышинский А.Я., Лозовский С.А. Американо-британские соглашения 1940-41 // Дипломатический словарь. М.: Государственное издательство политической литературы. 1948 // URL: http://dic.academic.ru/dic. nsf/dic_diplomatic/67 (дата обращения: 04.01.2013). В 1945 г. доля США в общей сумме иностранных инвестиций в Канаде составляла 70,4\% (для сравнения - в 1939 г. она равнялась 60,9\%); Великобритании 24,5\% (в 1939 г. - 36,2\%). - См. Позднеева Л.В. Канада в годы Второй мировой войны. М.: Наука, 1986. С. 40, 181.

18 Фултонская речь У. Черчилля // URL: http://www.coldwar. ru/churchill/fulton.php (дата обращения: 06.01.2013).
} 


\section{Международные отношения International Relations}

ских правительств и диктаторов, и к объединению стран Западной Европы и США для борьбы с экспансией Советской России. Именно это выступление, ставшее началом «холодной войны», привело к волне конституционных преобразований, выразившихся в демократизации общественной жизни, предоставлении гражданам широкого круга прав и свобод, гарантий конституционной законности, которая прокатилась в западноевропейских странах (Франция, Германия, Италия), начиная с 1946 г. Эти преобразования заложили политико-правовую основу для экономической интеграции Европы. Экономической основой явилась материальная помощь на восстановление послевоенной экономики Европы, предоставленная правительством США по так называемому плану Маршалла, озвученному им в 1947 г. В 1949 г. США, Канада и европейские страны образовали военно-политический союз, подписав договор об учреждении НАТО ${ }^{19}$.

Очередным толчком к объединению стран в Европе и Америке явилось окончание ядерного преимущества Запада перед Востоком, которое закончилось в августе 1949 г. испытанием атомной бомбы в СССР. Это событие резко активизировало объединительные процессы.

При одинаковой политической мотивации обеспечение военной безопасности и национальной самостоятельности регионов в противовес ядерным сверхдержавам США и СССР, втянувшимся в «холодную войну», - стартовые экономические и социально-правовые возможности и цели объединения стран Европы и Америки существенно отличались, что обусловило различный уровень объединительных процессов.

Европа на тот период имела индустриально развитые сбалансированные экономики, кооперированные связи которых требовали в целях развития расширения за пределы национальных государств. Объединение стран Америки стало осуществляться по двум направлениям, обусловленным правовым менталитетом и общностью интересов: США и Канады - достигнутой в годы войны, а также сложившимися в этот период преференционными торговыми отношениями; ${ }^{20}$ латиноамериканских стран - необходимостью устранения диспропорций экономик, ориентированных на экспорт сельскохозяйственной и сырьевой продукции, путем

\footnotetext{
19 См.: Беликова К.М. Общий рынок в Европе: интеграция и дифференциация // Международное публичное и частное право. 2005. № 1 (22). С. 14-17.

20 В 1947-1948 гг. Канада даже вела с США секретные переговоры о создании таможенного союза.
}

развития импортзамещающей национальной промышленности.

В Западной Европе: в 1951 г. учреждено Европейское объединение угля и стали (ЕОУС); в 1957 г. приняты договоры о создании Европейского экономического сообщества (ЕЭС) и Европейского сообщества по атомной энергии (Евратом) на территориях Франции, ФРГ, Италии, Бельгии, Нидерландов и Люксембурга.

Договором об образовании ЕЭС предусмотрено постепенное введение в действие концепции Общего рынка и общих политик в течение первых 12 лет, начиная с 1958 г. В течение этого периода следовало: снизить тарифные и нетарифные ограничения во взаимной торговле вплоть до полного их устранения; унифицировать таможенные правила и ввести общий таможенный тариф; постепенно устранить ограничения на свободу жительства и экономической деятельности, на движение капиталов внутри сообщества ${ }^{21}$. В соответствии с этим договором в странах ЕЭС на фоне мирового экономического подъема 60-70-х гг, вызванного разгаром «холодной войны» и приведшего к модернизации экономики, были устранены тарифные ограничения и создан к 1968 г. таможенный союз. К этому времени оказались не устранены нетарифные ограничения, препятствовавшие торговле между странами: физические (таможенный, паспортный, административный и др. контроль), технические (различия в национальных законодательствах и стандартах) и фискальные (различия в национальных системах налогообложения), которые при общем подъеме экономики казались несущественными. В 1967 г. вступил в силу так называемый «договор о слиянии»: для всех трех сообществ - ЕОУС, Евратом и ЕЭС - были образованы единые руководящие органы, а в 1970 г. положено начало интеграции стран ЕЭС в сфере внешней политики. В 1973 г. к ЕЭС, ставшим привлекательным для других стран Европы, присоединились Великобритания, Ирландия и Дания (так называемое «первое расширение» ЕЭС).

Послевоенный и период «холодной войны» вплоть до 1971 г можно охарактеризовать как период развития «зависимости Канады от США, намного превосходящей рамки здравого смысла» ${ }^{22}:$ к концу

\footnotetext{
21 Кашкин С.Ю., Калиниченко П.А. Общий рынок. // Глобалистика: Энциклопедия. М., 2003. С. 723.

22 Muirhead B.W. The Development of Postwar Canadian Trade Policy. The Failure of the Anglo-European Option. - Montreal \& Kingston, London, Buffalo: McGill-Queen`s University Press, 1992. Р. 179. Цит. по: Комкова Е.Г. Этапы и особенности североамериканской интеграции // Канада и НАФТА: итоги и перспективы североамериканской экономической интеграции. РАН. Инсти-
} 


\section{Региональные конфигурации международных отношений /}

Regional configuration of international relations

50-х гг. под контролем американского капитала находилось 70\% канадской нефти, 56\% обрабатывающей и $52 \%$ горнодобывающей промышленности. Кульминацией интеграции США и Канады стали 60-е гг., когда Соглашение о беспошлинной торговле продукцией автомобилестроения привело к полному сращиванию канадской и американской автомобильной промышленности. ${ }^{23}$

В Латинской Америке по примеру Европы в начале 1960 г. в Монтевидео была учреждена Латиноамериканская ассоциация свободной торговли (ЛАСТ) ${ }^{24}$ в составе Аргентины, Бразилии, Мексики, Уругвая, Чили, Парагвая и Перу. В 1961 г. к договору присоединились Колумбия и Эквадор, в 1966 г. - Венесуэла и в 1967 г. - Боливия. В результате в ЛАСТ вошли 10 государств Южной Америки и Мексика.

Договор Монтевидео 1960 г. $^{25}$ предусматривал создание в течение 12 лет зоны свободной торговли на территории латиноамериканских стран путем установления тарифа на товары в режиме наибольшего благоприятствования, который автоматически распространялся на всех участников ЛАСТ. В период развития национальных импортзамещающих экономик это положение явилось препятствием на пути урегулирования вопроса о тарифах в целом, а также сделало невозможным осуществление менее масштабных по территории интеграционных проектов. На практике страны перестали предлагать своим приоритетным региональным партнерам товары по льготным тарифам, поскольку при этом наносился ущерб национальным экономикам со стороны конкурирующих производителей третьих стран, из-за того, что все они обладали сходной на тот момент структурой внешней торговли. Повышение импортных таможенных пошлин в целях развития национальных экономик в рамках концепции «опоры на собственные силы» привело к самоизоляции латиноамериканского рынка. Однако в период 60-70 гг. рост торговли на территории стран-участниц ЛАСТ привел к увели-

тут США и Канады, Российское общество изучения Канады. М.: Институт США и Канады РАН, 2005. С. 47.

23 Американцы неоднократно пытались пересмотреть условия указанного соглашения, но безрезультатно. Действие его было прекращено по инициативе Канады лишь в 2001 г.

24 Беликова К.М. На пути к единому рынку в Южной Америке: факторы интеграции в экономике и праве // Вестник Российского университета дружбы народов. Серия «Юридические науки». 2005. № 1. С. 83-89.

25 Текст Договора см. на бразильском портале Universo Online (UOL) по адресу http://www2.uol.com.br/actasoft/actamercosul/espanhol/tratado_de_montevideo.htm (дата обращения: 06.01.2013). чению доли промышленных изделий в субрегиональном экспорте с 17\% до 28\% за счет кооперации и специализации промышленности латиноамериканских стран, что сопровождалось ростом ВВП в среднем на 6\% в год ${ }^{26}$. Решения Латиноамериканского парламента, созданного в виде делегаций от национальных конгрессов в 1964 г. для правовой координации экономической интеграции, носившие характер рекомендаций, не способствовали выработке единой внутренней и внешней тарифной системы. Таким образом, участие латиноамериканских стран в ЛАСТ явилось не началом экономической интеграции, а их тесным экономическим сотрудничеством, которое привело к развитию национальных экономик и создало условия для их интеграции, но не устранило их отставание и снижение темпов их роста по сравнению с мировым экономическим подъемом.

Мировой экономический кризис 70-х гг., порожденный распадом мировой колониальной системы; отмена США золотого паритета доллара, ознаменовавшая крах Бреттон-Вудской валютной системы (1971 г.); война на Ближнем Востоке 1973 г., вызвавшая многократное повышение цен на нефть и острый энергетический кризис, - привели к стагнации интеграционного процесса в Европе и в Америке.

Бесспорно, региональная интеграция по примеру Европы, приступившей к образованию Общего рынка в 1957 г., для латиноамериканских стран вектором развития, в реализации которого национальным латиноамериканским лидерам виделось достижение национальной безопасности.

При одинаковой с европейскими странами политической мотивации интеграции - обеспечение военной безопасности и национальной самостоятельности регионов в противовес ядерным сверхдержавам США и СССР, втянувшихся в «холодную войну», стартовые социально-экономические возможности и цели объединения стран Европы и Латинской Америке существенно отличались.

Региональная интеграция в Латинской Америке могла, с одной стороны, воплотить в жизнь идею объединения стран Латинской Америки, зародившуюся в начале XIX в. в виде романтической мечты лидера антиколониального движения С. Боливара о едином континенте с его неповторимой судьбой. C другой, бесспорен тот факт, что под влиянием права региональных интеграционных объединений усиливается и надгосударственное региональное, и одновременно взаимное правовое влияние стран,

\footnotetext{
26 Романова 3.И. Региональная интеграция - новые вызовы // Латинская Америка. 2003. № 8. С. 4-16.
} 


\section{Международные отношения International Relations}

входящих в то или иное интеграционное объединение, да и сами правовые системы претерпевают изменения. А такой процесс - целенаправленного внесения изменений в правопорядки государств, участвующих в процессе интеграции, с целью их гармонизации и унификации в определенных областях - оказался на тот момент для латиноамериканских стран преждевременным.

Кризис экономик, падение производства и массовая безработица привели к ослаблению наднационального начала властных структур ЕЭС, росту национального протекционизма и нарастанию бюджетных и валютных проблем ${ }^{27}$. В этой ситуации объективно стало невозможным устранить нетарифные ограничения, однако возможным оказалось осуществить организационные преобразования: создать новый институт ЕЭС - Европейский Совет на уровне глав государств и правительств (1974 г.); принять решение о введении прямых выборов в Европарламент; начать проведение региональной политики на основе учрежденного в 1975 г. Европейского фонда регионального развития; ввести в действие в 1978-1979 гг. Европейскую валютную систему (ЕВC).

Процесс интеграции США и Канады был остановлен Соединенными Штатами. Президент Р. Никсон, введя в 1971 г. чрезвычайные меры по спасению американского доллара в виде 10\%-ной пошлины на импорт, не сделал, как обычно, исключения для Канады, показав тем самым, что она для США всего лишь одна из других стран. Эта мера повлекла за собой развертывание Канадой политики рыночной диверсификации.

Спад в экономике в 1970-е гг. XX века, охвативший индустриальные государства, обернулся для латиноамериканских стран, хотя и сокращением рынков сбыта, но притоком дешевых кредитов с низкими процентными ставками и увеличением внутрирегианального экспорта в период 70-80 гг. с 28\% до $9 \%$, что усугубило их отставание от развитых стран. Это обусловило пересмотр концепции развития, ориентирующегося на собственные силы, на концепцию тесного регионального взаимодействия. В 1980 г. в Монтевидео страны-участницы ЛАСТ пересмотрели условия договора Монтевидео 1960 г., подписав новый договор ${ }^{28}$, который допускал заключение странами-участницами соглашений частичного

27 См.: Европейское сообщество: регулирование интеграционных процессов / отв. ред. М.М. Максимова, Ю.В. Шишков, Т. Паланкаи. М.: Наука, 1986.

28 Tratado de Montevideo de 1980 // URL: http://www.aladi.org/nsfaladi/juridica.nsf/tratadoweb/tm80 (дата обращения: 06.01.2013). охвата с другими странами или интеграционными блоками, права и обязанности по которым возникали только для государства их подписавших или присоединившихся к ним, и установление между ними преференционного таможенного режима, поскольку признавалось, что общее снижение тарифов не служит целям латиноамериканской интеграции, которая должна углубляться постепенно. В рамках новой концепции «открытого регионализма» такие соглашения рассматривались как «строительные блоки» для полного снятия тарифов в будущем между всеми членами вновь созданной организации - Латиноамериканской ассоциации интеграции (ЛАИ), сменившей ЛАСТ ${ }^{29}$.

Однако, начиная с 80-х гг. латиноамериканские страны оказались не в состоянии выплачивать внешние долги из-за возросших в этот период процентных ставок по кредитам. Во избежание социальных потрясений и нарастания на этом фоне коммунистического влияния в латиноамериканских странах США сменили стратегию «давления» на них путем предоставления этим странам займов МВФ под лозунгом «кредиты в обмен на реформы». Это позволило осуществить демократизацию латиноамериканских стран путем перехода от диктаторской, ранее пользовавшейся политической и экономической поддержкой США, формы правления к представительной. Таким образом, общенародные президентские выборы, проведенные в Аргентине в 1983 г., в Бразилии и Уругвае с 1985 г., в Парагвае, Чили, Боливии с 1989 г., ознаменовали переход от авторитарных режимов к правовому государству и гражданскому обществу. Этот переход сопровождался либерализацией экономики, выразившейся в приватизации государственной собственности, привел к реструктуризации внешних долгов путем конверсии краткосрочных долговых обязательств в долгосрочные и обмена долговых обязательств стран на акции приватизированных предприятий, и завершился проведением конституционных ре${\phi о р м^{30}}^{30}$ В результате - сумма внешнего долга стран

29 Капустин А.Я. Цит. соч.: Клаверен А.В. Латинская Америка на пути к открытому регионализму // Латинская Америка. 1997. № 6. C. 4-15; Carmona P. Objetivos y contenido de la integración regional: políticas de convergencia y efectos del ajuste // Documentos de Trabajo Publicados por CEFIR, 1993 // URL: http://www.cefir. org.uy/dt01doc.htm (дата обращения: 04.05.2005).

30 Беликова К.М. Правовое регулирование торгового оборота и кодификация частного права в странах Латинской Америки: монография. М.: Юстицинформ, 2010. С. 89-102 (480 с.); Дупас Ж. Новые дилеммы государственности, управления и интеграции с точки зрения логики глобализации // Латинская Америка. 2001. № 6. С. 50-59; Романова 3.И. Финансовый ры- 


\section{Региональные конфигурации международных отношений / Regional configuration of international relations}

Латинской Америки возросла в период 1971-1991 гг. с 24 до 460 млрд долл.

Реформирование латиноамериканских государств происходило одновременно с новой интеграционной политикой. В экономических отношениях между наиболее развитыми странами региона, например, Бразилией и Аргентиной, Колумбией и Венесуэлой, усилилась роль торгового обмена; создались условия для подписания соглашений в субрегионах: странах «южного конуса» (Аргентина, Бразилия, Парагвай, Уругвай, Чили) и странах Андской группы (Венесуэла, Боливия, Колумбия, Перу, Эквадор). Например, в 1985 г. Аргентина и Бразилия подписали «Декларацию Игуасу», целью которой являлось снижение политического недоверия друг к другу путем совместных усилий в противостоянии общим экономическим и политическим проблемам, возникающим при укреплении демократической системы, и учреждение для интеграции Совместной комиссии на высшем уровне ${ }^{31}$.

В середине 80-х г. Европа оказалась в роли заложника ядерных сверхдержав СССР и США, разместивших в 1983 г. ракеты средней дальности соответственно на территории Восточной и Западной Европы из-за войны СССР в Афганистане. Учитывая, что с начала 80-х гг. в странах Восточной Европы и СССР экономический кризис перерос в политическую нестабильность, повлекшую за собой политические преобразования, страны ЕЭС с целью стабилизации западноевропейского региона приняли решение об углублении интеграции и в 1986 г. подписали Единый Европейский Акт (EEA) ${ }^{32}$ о создании единого внутреннего рынка. Он установил срок обязательного устранения нетарифных ограничений во всех странах ЕЭС - до 31 декабря 1992 г., а также юридически закрепил сложившийся к тому времени механизм координации внешней политики стран ЕЭС. В этот период произошло «второе расширение» ЕЭС - в Сообщества были приняты Греция (1981 г.), Испания и Португалия (1986 г.).

В 1985 г. на встрече президента США Р. Рейгана и премьер-министра Канады Б. Малруни была принята (впервые после 1971 г.) Декларация о торговле, в которой ставилась задача создания механизма и

нок в условиях глобализации // Латинская Америка. 2000. № 9. С. 4-16; Ивлева Т. Н. Как бороться с финансовыми кризисами: три подхода // Латинская Америка. 2001. № 3. С. 4-13.

31 Гражданское и торговое право зарубежных стран: учеб. пособие / под общ. ред. В.В. Безбаха и В.К. Пучинского. М.: МЦФЭР, 2004. С. 74-75.

32 Single European Act (1986) // Official Journal L 169 of 29 June 1987. изучения всех возможностей по устранению барьеров, существующих на пути расширения двусторонней торговли. В результате длительных переговоров Соглашение о создании американо-канадской зоны свободной торговли (ФТА) было заключено в 1988 г. и вступило в силу с 1 января 1989 г.

Стремительность развития политических событий в странах Восточной Европы и Советском Союзе привела к краху идеологической системы «Востока», распаду в 1991 г. СССР, образованию множества государств, провозгласивших в качестве основы своего дальнейшего развития принципы демократии и национальной независимости. Национал-радикальные лозунги вновь образовавшихся стран не только шокировали давно прошедшую эту стадию Западную Европу, но и активизировали в ней ультраправые силы. Под угрозой развития националистских движений интеграционные процессы в ЕЭС стали быстро развиваться в сторону углубления интеграции. Договор о Европейском Союзе $1992 \Gamma^{33}$ (Маастрихтский договор) юридически закрепил: переход от Общего рынка к экономическому и валютному союзу; преобразование ЕЭС в Европейское Сообщество; сотрудничество полиций и судебных органов на территории Общего рынка.

На фонеразвития интеграционногопроцессавЕвропе, декларировавшей в 1986 г. создание к 1992 г. Европейского Союза (ЕC), Аргентина и Бразилия в 1986 г., действуя в рамках Договора Монтевидео 1980 г., активизировали взаимное экономическое сотрудничество и подписали соглашение, содержащее Программу экономической интеграции и сотрудничества в различных отраслях национального хозяйства. В 1988 г. Уругвай, а в 1990 г. Парагвай, основываясь на существующих двусторонних договоpax с Аргентиной и Бразилией, присоединились к процессу региональной экономической интеграции. В 1989 г. был активизирован интеграционный процесс в Андской группе, созданной еще в 1969 г. в рамках ЛАСТ и преобразованной в Андское сообщество наций ${ }^{34}$.

Выдвинутая США в 1990 г. «Инициатива для Америк» о создании к 2005 г. Всеамериканской зоны свободной торговли (АЛКА) изначально характеризовалась концептуальными разногласиями ${ }^{35}$ между

\footnotetext{
33 Treaty on European Union (1992) // Official Journal C 191 of 29 July 1992.

34 Лавут А.А. Андская группа: от застоя к модернизации? // Латинская Америка. 1997. № 3. С. 11-17.

35 Flynn M. Brazil Increasingly Unenthusiastic about U.S. FTAA Proposals. Has Bush's "Century of the Americas" already come and gone? February 1, 2002 // URL: http://www.cipamericas.org/
} 


\section{Международные отношения International Relations}

позициями «севера» (США) и «юга» (Бразилии). США настаивали на присоединении к НАФТА других стран региона в индивидуальном порядке и заключении соглашений по секторам экономической деятельности $^{36}$. Бразилия отвергла создание АЛКА на неравноправных условиях под главенством НАФТА и предложила всемерное развитие и поэтапное слияние региональных интеграционных объединений.

26 марта 1991 г. Аргентина, Бразилия, Парагвай и Уругвай подписали Асунсьонский договор, положивший начало созданию Южноамериканского общего рынка - МЕРКОСУР, в котором внутренняя отмена таможенных пошлин осуществлялась путем их регулярного снижения каждые 6 месяцев в течение короткого переходного периода - с момента его подписания до 31 декабря 1994 г.

С целью обеспечения политического равновесия в Европе в 1992 г. было принято решение о расширении Общего рынка путем поэтапной интеграции стран ЕС с западноевропейскими странами ассоциации свободной торговли (ЕАСТ) - Австрией, Финляндией, Швецией - которые стали членами ЕС с 1995 г. («третье расширение») ${ }^{37}$. Однако та же угроза развития националистских тенденций явилась объективной необходимостью начала поэтапной интеграции ЕС со странами Восточной Европы «четвертого расширения» - Польшей, Венгрией, Чехией, Словакией, Словенией, Болгарией, Румынией и странами Балтии: Эстонией, Латвией и Литвой, которое было положено подписанием в Коппенгагене в 1993 г. ряда соглашений ЕС с этими странами об интеграции, кооперации и сотрудничестве.

Образование в 1991 г. МЕРКОСУР, а в 1992 г. Европейского Союза (ЕС) активизировало интеграционные процессы в Северной Америке, и в декабре 1992 г. США, Канада и Мексика подписали соглашение о создании с 1 января 1994 г. Североамерикан-

archives/1171 (дата обращения: 31.07.10); Gudynas E. El MERCOSUR ante el ALCA: Nuevas tensiones y nuevas opciones, 29 de octubre de 2003 // URL: http://www.cipamericas.org/archives/1126 (дата обращения: 31.07.10); Flynn M. Bush and Lula: A Collision of Two Worlds, July 10, 2003 // URL: http://www.cipamericas.org/ archives/1155 (дата обращения: 31.07.10).

36 Влияние США на страны Латинской Америки всегда носило характер избирательного экономического давления, а в период демократических преобразований в них, должно было поддержать и ускорить эти преобразования. Практически такая политика привела к дискриминации торговли с Бразилией и протекционизму в отношениях с Аргентиной.

37 Право Европейского Союза: правовое регулирование торгового оборота: учеб. пособие / под ред. В.В. Безбаха, А.Я. Капустина, В.К. Пучинского. М.: ЗЕРЦАЛО, 2000. С. 7-10. ской зоны свободной торговли (НАФТА) ${ }^{38}$. Сработал так называемый «демонстрационный эффект», для практической реализации которого, безусловно, потребовалась политическая воля всех трех государств, решивших образовать зону свободной торговли, при этом все три страны-участницы НАФТА руководствовались различными мотивами: США - экономического проникновения в Южную Америку с целью расширения рынков сбыта и обеспечения стабильности энергетических и других сырьевых поставок в масштабе континента («Инициатива для Америк»); Канада - закрепления статуса привилегированного торгово-экономического партнера самой могущественной страны мира с доступом к самому емкому в мире рынку - США, Мексики и Южной Америки; Мексика - приобщения без особых усилий к числу промышленно-развитых стран в короткий срок (до 10-15 лет) в продолжение неолиберальных реформ, предпринятых правительством Мексики в начале 80-х гг., отказавшимся от импортозамещающей стратегии развития страны.

Участие в МЕРКОСУР стран, имеющих совершенно разные стартовые возможности, обусловленные значительной разницей в уровне модернизации социально-экономических структур и степени проведения реформ, послужило мощным стимулом для развития экономик на основе их дополняемости и роста взаимной торговли, поэтому в 1993 г. Бразилия выступила с предложением создания Южноамериканской зоны свободной торговли (АЛКАС).

Подводя итоги переходного периода в декабре 1994 г. в г. Оуро-Прето руководители странучастниц МЕРКОСУР констатировали, что к 1 января 1995 г. в экономической сфере были созданы зона свободной торговли, распространявшаяся на $90 \%$ товаров согласованной таможенной номенклатуры, и таможенный союз, распространявшийся на $85 \%$ товаров; и установили, что распространение режима свободной торговли на $100 \%$ внутризонального товарообмена должно осуществиться к 2000 г., а принятие общего внешнего тарифа на все виды продукции в Аргентине и Бразилии - к 2001 г., в Уругвае и Парагвае - к 2006 г.

В целях создания условий для свободного перемещения рабочей силы: заключены четырехсторонние соглашения о взаимном признании аттестатов, дипломов и других документов о начальном, среднем, высшем и постуниверситетском образо-

\footnotetext{
38 Текст Соглашения о создании Североамериканской зоны свободной торговли см. на оф.с. Секретариата НАФТА по адреcy http://www.nafta-sec-alena.org (дата обращения: 03.01.2013).
} 


\section{Региональные конфигурации международных отношений /}

Regional configuration of international relations

вании; существенно упрощены пограничные формальности для перемещения физических лиц на территории МЕРКОСУР. Одновременно было принято решение о расширении интеграционных процессов на политическую, военную и гуманитарную сферы, что выразилось в развитии сотрудничества университетов, расширении культурного и информационного обмена, проведении с 1996 г. регулярных совместных военных учений. ${ }^{39}$

Начало консолидации внутризональной политики стран-участниц МЕРКОСУР было положено на Сан-Луисском форуме в 1996 г. подписанием Президентских Деклараций о демократических гарантиях в странах-участницах МЕРКОСУР и о провозглашении их территории зоной мира и развито в 1998 г. «Протоколом Ушуая», ставшим неотъемлемой частью Асунсьонского договора. Это окончательно оформило МЕРКОСУР к 1998 г. в виде политико-экономического блока.

Позиция внешней политики МЕРКОСУР, основанная на концепции «открытого регионализма», стала формироваться под влиянием процесса образования АЛКА в рамках «Инициативы для Америк» и развития отношений со странами Андского сообщества, Азиатско-Тихоокеанского региона (АТР), ЕС и НАФТА ${ }^{40}$.

В 1992 г. установлены официальные отношения МЕРКОСУР с ЕС, оформленные в 1995 г. рамочным соглашения о создании к 2005 г. зоны свободной торговли на территории ЕС и МЕРКОСУР.

На правах ассоциированных членов в 19951996 гг. к МЕРКОСУР присоединилась Боливия, а в 1994-1996 гг. Чили. В 1998 г. было подписано рамочное соглашение МЕРКОСУР с Андским сообществом о создании зоны свободной торговли.

Однако, мировой финансовый кризис 19981999 гг. повлек за собой на фоне смены политического руководства в Аргентине и Бразилии кризис интеграционных процессов в МЕРКОСУР, вызванных инфляцией, наличием долгов, ростом безработицы и социального недовольства реформами. Эффект от экономической интеграции был существенно снижен последовавшими друг за другом процессами девальвации почти на 70\% бразильского реала, кризиса экономики Аргентины, вве-

\footnotetext{
39 Cronologia do Mercosul (1985-1999): Centro Brasileño de Documentación y Estudios de Bacia do Prata (CEDEP), Universidad Federal de Río Grande do Sul (UFRGS) // URL: www.cedep.ifch.ufrgs.br/ Cronologiamercosul/cron_mercosul.doc (дата обращения: 31.07.10).

40 Hansen-Kuhn K. Free Trade Area of the Americas. December 1, 1996 // Foreign Policy In Focus, 6(12), 2001 // URL: http://www. fpif.org/reports/free_trade_area_of_the_americas (дата обращения: 31.07.10).
}

дения протекционистских мер, сокращения аргентино-бразильского товарооборота, девальвации аргентинского песо и поставил под вопрос сам факт существования МЕРКОСУР. Однако политическая воля нового руководства стран и глубокая дополняемость экономик Аргентины и Бразилии привели в 2000 г. к решимости «перезапуска МЕРКОСУР», продолжению и углублению интеграции. Страны МЕРКОСУР приступили к разработке концепции создания единой валюты и единой социальной программы ${ }^{41}$.

В этот период практическая реализация «четвертого расширения» общего рынка ЕС при интеграции стран Западной и Восточной Европы с разным уровнем экономического и политического развития потребовала выработки новой концепции - дифференцированной интеграции в форме продвинутого сотрудничества, закрепленной в Амстердамском договоре $1997 \Gamma^{42}$ и окончательно сформулированной в Ниццком договоре 2001 г. ${ }^{1}$ В этих договорах изложено положение о том, что страны-участницы, которые способны и желают быстрее двигаться вперед, могут это делать, не дожидаясь остальных. Другие же, которые желают остаться в стороне, не должны им в этом препятствовать. Выработке такой концепции способствовал тот факт, что еще в ЕЭС существовали интеграционные организации - Экономический союз стран Бенилюкс, объединения стран в рамках НАТО и ЗЕС, а в ЕС - объединения стран в «зону Евро» и в «Шенгенскую зону».

В процессе переговоров о создании АЛКА в 1998-2002 гг. стратегии США разобщения латиноамериканских стран Бразилия противопоставила активную политику укрепления их сотрудничества путем развития региональной инфраструктуры, особенно энергетики, и создания Южно-американской зоны свободной торговли - АЛКАС, что встретило поддержку всех южноамериканских государств. В 2002 г. МЕРКОСУР и Андское сообщество подписали соглашение о создании зоны свободной торговли между блоками к концу 2003 г. на основании договоров о тарифных преференциях, заключаемых странами МЕРКОСУР со странами Андского сообщества индивидуально ${ }^{43}$. В 2003 г.

\footnotetext{
4110 лет Меркосур // Латинская Америка. 2001. № 7. С. 19-38.

42 Treaty of Amsterdam amending the Treaty on European Union, the Treaties establishing the European Communities and related acts // Official Journal C 340, 10 November 1997.

43 Глинкин А.Н. Соглашение по АЛКА: за год до финиша // Латинская Америка. 2004. № 1. С. 4-21; Романова 3.И. Региональная интеграция - новые вызовы // Латинская Америка. 2003. № 8. C. 4-16.
} 


\section{Международные отношения International Relations}

после непростых переговоров ассоциированным членом МЕРКОСУР стало Перу. Восьмая конференция министров торговли государств западного полушария, состоявшаяся 20-21 ноября 2003 г., едва не закончилась провалом из-за стремления США во что бы то ни стало «продавить» свою модель создания АЛКА. Решение о продолжении переговоров и их завершении к 1 января 2005 г. было принято после достижения консенсуса относительно новой стратегии создания АЛКА. Суть изменения состоит в том, что отныне каждая страна самостоятельно, а не как участница какого-либо регионального объединения, будет определять степень своего участия в соглашении, а ее права будут зависеть от взятых на себя обязательств ${ }^{44}$. В рамках такого подхода в мае 2004 г. США заключили двусторонние соглашения о зоне свободной торговли с рядом стран Центральной Америки - Сальвадором, Гватемалой, Гондурасом, Никарагуа и Коста-Рикой, а в августе 2004 г. - с Доминиканской республикой; заключенное соглашение было ратифицировано парламентом Сальвадора в декабре 2004 г. $^{45}$ Такие двусторонние соглашения действуют между США и Мексикой и США и Чили.

В декабре 2004 г. Венесуэла, Колумбия и Эквадор $^{46}$ стали ассоциированными членами МЕРКОСУР, что закрепило процесс объединения МЕРКОСУР с Андской группой. Одновременно проведенные 711 февраля 2005 г. США переговоры, начатые в описанном выше формате о заключении двусторонних соглашений с Боливией, Колумбией, Перу и Эквадором, завершились, подписанием такого соглашения с Колумбией в 2007 г. и Перу в 2009 г. и т.д. ${ }^{47}$ В июле 2006 г. подписан Протокол о присоединении к МЕР-

44 См., например, материалы Круглого стола Института Латинской Америки «Восходящие страны-гиганты на мировой сцене XXI века» // Латинская Америка. № 6, 7. 2005. С. 4-18.

45 См., напр.: Ahora se obliga a Centroamérica y otros países a suscribir TLC bilaterales que los pueblos rechazamos. Fuertes reacciónes en toda América Latina frente a los TLC. 17/2/05 // URL: www.revistapueblos.org/spip.php?article153 (дата обращения: 07.08.10).

46 MERCOSUR/CMC/DEC. № 44/04: Atribución a la República de Colombia de la condición de estado asociado del MERCOSUR // URL: http://www.mercosur.int/msweb/Normas/normas_web/Decisiones/ES/DEC044-004-EstAsocColCB4mbia-ES_Acta2-04.PDF (дата обращения: 31.07.10) и MERCOSUR/CMC/DEC. № 43/04: Atribución a la República del Ecuador de la condición de estado asociado del MERCOSUR. URL: http://www.mercosur.int/msweb/ Normas/normas_web/Decisiones/ES/DEC043-004-EstAsocEcuador-S_Acta2-04. PDF (дата обращения: 31.07.10).

47 Entró en vigencia el TLC Perú-EE.UU. 16 de Enero del 2009 // URL: http://www.rpp.com.pe/2009-01-16-entro-en-vigencia-el-tlcPerú-ee-uu-noticia_157866.html (дата обращения: 07.08.10)
КОСУР в качестве полноправной страны-участницы Венесуэлы $^{48}$; в декабре 2012 г. - Протокол о присоединении к МЕРКОСУР в качестве полноправной страны-участницы Боливии ${ }^{49}$. В июле 2012 г. Венесуэла стала полноправной страной-участницей МЕРКОСУР ${ }^{50}$, заняв место Парагвая, членство которого в МЕРКОСУР было прекращено согласно примененным положениям Протокола Монтевидео по вопросу приверженности демократии в МЕРКОСУР от 20 декабря 2011 г. - Ушуаи II $^{51}$ после того, как там произошел государственный переворот: враждебно настроенный к главе государства парламент при помощи процедуры импичмента сместил законно избранного президента Фернандо Арминдо Луго Мендеса ${ }^{52}$.

Как видим, как и в ЕС, где интеграция осуществляется в настоящее время в форме продвинутого сотрудничества с 2004 г. включением в ЕС пяти бывших социалистических стран (Польша, Словакия, Словения, Чехия, Венгрия), трех бывших республик СССР (страны Балтии) и двух средиземноморских государств (Кипр, Мальта) ${ }^{53}$, и в Латинской Америке - с 2005 г. с принятием Венесуэлы, Колумбии и Эквадора ассоциированными членами МЕРКОСУР, в Северной Америке интеграция развивается «на двух уровнях», «на двух скоростях», когда динамика процессов задается США и Канадой, а Мексика присоединяется к их инициативам, в том случае, когда

48 Protocolo de Adhesión de la República Bolivariana de Venezuela al MERCOSUR. 4/07/2006 // URL: http://www.mercosur. int/innovaportal/file/2485/1/2006_PROTOCOLO_ES_AdhesionVenezuela.pdf (дата обращения: 09.01.2013)

49 Protocolo de Adhesión del Estado Plurinacional de Bolivia al MERCOSUR. 7/12/2012 // URL: http://www.mercosur.int/innovaportal/file/2485/1/protocolo_adhesion_bolivia_al_mercosur. pdf (дата обращения: 09.01.2013)

50 См., напр.: Venezuela se incorporó formalmente al Mercosur. 31 de julio de 2012 // URL: http://www.lanacion.com.ar/1494926-todolisto-para-que-venezuela-se-incorpore-al-mercosur (дата обращения: 09.01.2013)

51 См., напр.: Protocolo de Montevideo sobre Compromiso con la Democracia en el MERCOSUR (Ushuaia II). 20/12/2012 // URL: http://www.mercosur.int/innovaportal/file/2485/1/ushuaia_ii.pdf (дата обращения: 09.01.2013). Eduardo Arce. Polémica en torno a la firma del Protocolo de Montevideo en el Mercosur. // E`a. Periodico de Inter-pretacion y Analisys. Enero 11, 2012 // URL: http:// ea.com.py/polemica-en-torno-a-la-firma-del-protocolo-de-montevideo-en-el-mercosur/ (дата обращения: 09.01.2013).

52 Моисеев А. Демократия дала сбой в Парагвае // Международная жизнь. 16/07/2012 // URL: http://ref.interaffairs.ru/read. php?item=8610 (дата обращения: 09.01.2013)

53 Clubbing together // The Economist, November 22nd-28th 2003. P. 13-14. 


\section{Региональные конфигурации международных отношений /}

Regional configuration of international relations

считает это возможным и необходимым для себя. Как и МЕРКОСУР НАФТА действует в рамках концепции «открытого регионализма». Такое положение давало исследователям этого интеграционного объединения констатировали неоднозначность результатов функционирования НАФТА, поскольку наряду с положительными результатами имеется и вполне ощутимый отрицательный эффект ${ }^{54}$.

В 1993 г. Зб. Бжезинский сказал о том, что Североамериканская зона свободной торговли в будущем сможет стать ядром Панамериканского общего рынка, оказывая влияние на все страны Западного полушария, включая и Кубу ${ }^{55}$. После событий 11 сентября 2001 г. США проводят политику унилатерализма, а Канада предпочитает решать возникающие вопросы на двусторонней основе - отдельно с Мексикой, отдельно с США, что представляет собой отход от проводимой ранее политики трилатерализма; Мексика старается придерживаться трехстороннего подхода. Тем не менее, зона свободной торговли между тремя странами НАФТА состоялась к 1 января 2003 г.

Провал же в 2005 г. переговоров о Всеамериканской зоне свободной торговле, после которого США, Канада и Мексика встали на путь заключения сепаратных соглашений о свободной торговле с экономически развитыми и прозападно настроенными странами, стал фактором, начавшим размывать преимущества, первоначально имевшиеся только у участников НАФТА ${ }^{56}$. В числе других причин уменьшения значения НАФТА отмечаются следующие:

- 1 января 2008 г. истек официальный 15-летний срок, на который оно было рассчитано, так что формально соглашение считается выполненным;

- реализация договоренностей по итогам Уругвайского раунда ГАТТ заметно понизила ставки таможенных пошлин по тарифу Режима наиболее благоприятствуемой нации для всех стран-участниц. А с созданием в 1995 г. ВТО укрепился механизм разрешения международных торговых споров, были выработаны определения мер чрезвычайной торговой защиты и

\footnotetext{
54 КомковаЕ.Г.Канада-США:напутиктаможенномусоюзу?// США - Канада. Экономика, политика, культура. 2004. № 5. С. 32-48; Она же. Канада и НАФТА: экономические итоги десятилетия // США - Канада. Экономика, политика, культура. 2005. № 12. C. 3-24.

55 Brzezinski $\mathrm{Zb}$. Out of control. Global Turnout on the Eve of the 21 Century. N.Y.-Toronro, 1993. P. 221.

56 Комкова Е.Г. Канада в процессах североамериканской экономической интеграции: теоретические и практические аспекты (на примере НАФТА): автореф. дис. ... д-ра экон. наук. М., 2011.41 c.
}

заключены некоторые важные соглашения по тем вопросам, пионером рассмотрения которых когда-то выступило соглашение НАФТА. Это постепенно девальвировало те преференции, которые в 1994 г. предоставили друг другу США, Канада и Мексика;

- $\quad$ в процессе реализации ФТА и НАФТА выявились присущие им недостатки и «провалы», одним из которых является нежелание США подчиняться невыгодным решениям трибуналов НАФТА по отдельным торговым спорам, имеющим для них особо важное значение, что подрывает доверие к НАФТА у Канады и Мексики;

- происходит некоторое ослабление экономических позиций США в мире при усилении роли Китая, Индии, Бразилии ${ }^{57}$ - в 2009 г. эти страны, объединившись с Россией, создали экономический форум БРИК - обозначаемый ныне (с присоединением к БРИК Южной Африки) аббревиатурой БРИКС.

В связи с этим высказывается мнение о неопределенности будущего НАФТА, и делается предположение о том, что дальнейшее управление североамериканской экономической интеграцией будет происходить не путем пересмотра соглашения НАФТА, а путем движения по параллельным трекам - формальным (через заключение других соглашений), так и неформальным (в виде создания разного рода континентальных межведомственных комиссий, рабочих групп и т.п. на общефедеральном, региональном, муниципальном уровнях $)^{58}$. Оба варианта воплощаются в жизнь (напр., ЕС, БРИКС), какой вариант развития подойдет НАФТА, покажет время.

На фоне выработки приемлемых решений между США и странами Латинской Америки происходят активные переговоры о расширении сотрудничества, особенно экономического, между ЕС и МЕРКОСУР.

В соответствии с ними в 2001-2003 гг. между ЕС и МЕРКОСУР происходил обмен предложениями об уровне снижения тарифов на различные группы товаров. На встречах представителей обоих блоков обсуждались вопросы, касающиеся государственной помощи, инвестиций, электронной торговли, порядка урегулирования споров, санитарных и фитосанитарных стандартов и поставок спиртных напитков.

\footnotetext{
57 См.: Актуализация процесса взаимодействия стран БРИКС в экономике, политике, праве: Материалы Научного семинара. Москва, 9 октября 2012 г. / отв. ред. и сост. Беликова К.М. М.: Сенат Пресс, 2012. 251 с.

58 Комкова Е.Г. Канада в процессах североамериканской экономической интеграции: теоретические и практические аспекты (на примере НАФТА): автореф. дис. ... д-ра экон. наук. М., 2011. 41 с.
} 


\section{Международные отношения International Relations}

Однако после того как на сделанные МЕРКОСУР предложения ответа со стороны ЕС не последовало, позиция ЕС была признана странами-участницами МЕРКОСУР негибкой, и блок приостановил переговоры о создании зоны свободной торговли в части вопросов, вызвавших противоречия. Предложение о продолжении переговоров по иным вопросам, например, о порядке урегулирования споров, было поддержано.

В 2005 г. в рамках бизнес-форума МЕРКОСУР-ЕС была поддержана инициатива «перезапуска» проводимых переговоров, исходя из того, что ЕС является самым крупным деловым партнером МЕРКОСУР 59 . В рамках этой инициативы Комиссия ЕС приступила к разработке Второй региональной индикативной программы сотрудничества ЕС-МЕРКОСУР на 2007 2013 гг.

Что касается отношений с США в плане создания АЛКА, категорический отказ был получен США от Аргентины, Бразилии и Венесуэлы; также не согласны на подобные соглашения Боливия, Парагвай и Эквадор ${ }^{60}$. Так, еще в 2006 г. посол Венесуэлы в РФ А. Наварро Рохас заявил: «Венесуэла не будет участвовать в АЛКА, ибо этот проект направлен в основном на защиту экономических интересов Соединенных Штатов. И это не пустые слова, например, в рамках АЛКА США жестко защищают интересы своих фермеров в области сельского хозяйства. И как результат - производство маиса (кукурузы) в Мексике, которая наиболее тесно связана с США, практически ликвидировано» ${ }^{61}$. Более того, на

59 Mercosur: Commission approves EUR 4 million to support regional integration. Brussels, 12 March 2004. URL: http://europa. $\mathrm{eu} / \mathrm{rapid} /$ pressReleasesAction.do?reference $=\mathrm{IP} / 04 / 331 \&$ format $=\mathrm{HT}$ ML\&aged=0\&language=EN\&guiLanguage $=$ en $($ дата обращения: 31.07.10); MERCOSUR - Unión Europea // URL: http://www.sice. oas.org/tpd/mer_eu/mer_eu_e.asp (дата обращения: 31.07.10).

60 См., напр.: Perú у Colombia reanudarían el diálogo por un TLC con la UE en enero de 2009. Jueves, 13 de Noviembre de $2008 / /$ Andina // URL: http://www.adnmundo.com/contenidos/econycom/ Perú_colombia_dialogo_tlc_ue_enero_2009_can_bolivia_morales_belaunde_ce_131108.html (дата обращения: 31.07.10); Ante el estancamiento del TLC con EEUU, Colombia se asocia con Canadá y China. Viernes, 21 de Noviembre de 2008 // Reuters // URL: http://www.adnmundo.com/contenidos/econycom/estancamiento_ tlc_eeuu_colombia_canada_china_apec_estados_unidos_congreso_ uribe_ce_211108.html (дата обращения: 31.07.10).

61 Репортаж с совместной пресс-конференции послов Республики Кубы и Боливарианской Республики Венесуэла в Российской Федерации Хорхе Марти Мартинеса и Алексиса Наварро Рохаса, которая была посвящена проблемам интеграции в Латинской Америке. 5 июля 2006 г. // Электронный выпуск «Экономической и философской газеты» // URL: http:// www.eifgaz.ru/app-262006.htm (дата обращения: 31.07.10). предложения США о создании АЛКА Венесуэла ответила собственным интеграционным проектом «Боливарианской альтернативой для Америк» (АЛБА — «Alternativa Bolivariana para las Americas» ALBA - исп.), начало которой было положено в 2004 г. заключением соглашения о создании АЛБА У. Чавесом и Ф. Кастро ${ }^{62}$.

Дальнейшее развитие интеграционных процессов на южноамериканском континенте также как и на северной его части, на наш взгляд, многовариантно и зависит от политических и экономических факторов. Прогнозы развития описаны в многочисленных работах, какой вариант развития возобладает, покажет время ${ }^{63}$.

Развитие законодательного оформления интеграционного процесса в Европе с момента принятия Ниццкого договора связывалось с осознанием европейцами необходимости проведения реформ в целях повышения эффективности и демократизации ЕС путем принятия Договора, учреждающего конституцию для Европы (Treaty establishing a Constitution for Europe), подписанного в 2004 г. 25-ю тогдашними странами-участницами и 3-мя странами-кандидатами на членство в ЕС. Одобрение текста Договора, как парламентами стран-участниц, так и посредством проводимых в них референдумов, которое, как предполагалось первоначально, завершится к 1 ноября 2006 г., успехом не увенчалось. Так, например, хотя и прогнозируемыми, но отрицательными были итоги

62 Acuerdo entre el Presidente de la República Bolivariana de Venezuela y el Presidente del Consejo de Estado de Cuba, para la aplicación de la Alternativa Bolivariana para las Américas. 14/12/2004 // URL: http://www.alianzabolivariana.org/modules.php?name=Conte nt\&pa=showpage\&pid=2079 (дата обращения: 31.07.10).

63 См., например, Katz C. Alternativas al ALCA. MERCOSUR y ALCA: del fracaso a la sumisión. // Progreso Semanal, enero 2004 // URL: http://www.diariomardeajo.com.ar/alternativasalalca.htm (дата обращения: 31.07.10); Peña F. Does Mercosur have future? May 2003. URL: http://www.felixpena.com.ar/index. php?contenido=wpapers (дата обращения: 31.07.10); Peña F. Reflexiones sobre el Mercosur y su futuro, Septiembre 2002 // URL: http://www.felixpena.com.ar/index.php?contenido=wpapers (дата обращения: 31.07.10); EE.UU. acusa a MERCOSUR de trabar creación del ALCA. // Cadena Global/AP 19 de noviembre del 2004; Dura respuesta del MERCOSUR a acusaciónes de EE.UU. // Diario HOY, 20 de noviembre del 2004; EE.UU. y Brasil difieren en temas relaciónados con el ALCA. // Prensa Latina, 27 de octubre del 2004; Rio Group not too enthusiastic about FTAA. // Mercopress, Saturday, 06 November URL: en.mercopress.com/2004/11/06/rio-group-nottoo-enthusiastic-about-ftaa (дата обращения: 31.07.10); Silvia E. Stamato. El futuro del Mercosur. Perspectivas. // Union Industrial de San Martin. 9 de Enero de 2013 // URL: http://www.uidgsm.com.ar/ modules.php?name=News\&file=article\&sid=17 (дата обращения: 09.01.2013) и др. 


\section{Региональные конфигурации международных отношений /}

Regional configuration of international relations

референдумов во Франции (29 мая 2005 г.) и в Нидерландах (1 июня 2005 г.).

Поэтому на смену этой парадигме мышления пришла другая идея, - как и раньше, строить отношения между странами-участницами на основе договора, являющегося международным соглашением, для ратификации которого необходимы лишь действия национальных парламентов. Таким договором стал Договор о внесении изменений в Договор о Европейском союзе и Договор об учреждении Европейского сообщества 2007 г. или Договор о реформе ЕС, утвержденный на 13 ноября 2009 г. всеми 27 странами-участницами и получивший наименование Лиссабонского соглашения ${ }^{64}$. Это соглашение призывает отказаться от некоторых одиозных положений Договора, учреждающего конституцию для Европы (таких как введение атрибутов государственности EC в виде гимна, флага и др.) при одновременном реформировании системы управления. До настоящего времени руководство ЕС осуществляется по той же схеме, которая использовалась, когда членами Евросоюза были 12 стран-участниц, что, безусловно, снижает эффективность руководящих органов ЕС и вызывает необходимость изменений.

С одной стороны, беспрецедентная в истории межгосударственных отношений экономическая интеграция европейских стран с совершенно разными стартовыми возможностями и значительными различиями в уровне социально-экономической модерни- зации и стадиях проводимых в них рыночных реформ представляет интерес для изучения в контексте участия РФ в таких интеграционных объединениях как СНГ, ЕврАзЭС и др. С другой стороны, ЕС представляет собой объединение стран, принадлежащих к разным системам права - континентальной и англосаксонской, серьезные расхождения между которыми сохраняются до сих пор, несмотря на сближение вследствие расширяющихся отношений между странами. Какое будущее ждет ЕС, покажет время.

Сделанный обзор интеграционных процессов на Американском континенте и в Европе, показывает, что процесс интеграции стран существенно зависим от внешних экономических и политических факторов, и прослеживаются следующие закономерности:

1) в периоды мировых экономических кризисов интеграция замедляется, в периоды политических получает новый импульс к развитию в направлении углубления и расширения территории за счет соседних государств независимо от уровня их развития;

2) интеграционные объединения стран с различным уровнем экономического и социально-политического развития имеют тенденцию к «дифференцированной интеграции» и «открытому регионализму», что приводит к созданию более мелких внутренних образований, направленных на углубление интеграционных процессов между их участниками в форме продвинутого сотрудничества или к развитию интеграции на «нескольких скоростях».

\section{Источники:}

1. 10 лет Меркосур // Латинская Америка. 2001. № 7. С. 19-38.

2. Актуализация процесса взаимодействия стран БРИКС в экономике, политике, праве: Материалы Научного семинара. Москва, 9 октября 2012 г. / отв. ред. и сост. Беликова К.М. М.: Сенат Пресс, 2012. 251 с.

3. Аннерс Э. История европейского права (пер. со швед.) / Ин-т Европы. М.: Наука, 1994.

4. Бахин С.В. Понятие и механизмы международно-правового сближения правовых систем. // Российский ежегодник международного права / Российская ассоциация международного права; Ред. кол.: Л.Н. Галенская (гл. ред.) и др. СПб.: СКФ «Россия - Нева», 2001.

5. Безбах В.В., Беликова К.М. Что заставляет латиноамериканцев объединяться? Образование Южноамериканского Общего рынка и его развитие. // Внешнеторговое право. 2006. № 1(6). С. 8-12.

6. Беликова К.М. На пути к единому рынку в Южной Америке: факторы интеграции в экономике и праве // Вестник Российского университета дружбы народов. Серия «Юридические науки». 2005. № 1. С. 83-89.

7. Беликова К.М. Общий рынок в Европе: интеграция и дифференциация // Международное публичное и частное право. 2005. № 1 (22). С. 14-17.

8. Беликова К.М. Правовое регулирование торгового оборота и кодификация частного права в странах Латинской Америки: монография. М.: Юстицинформ. 2010. С. 89-102 (480с.)

9. Берман Г.Дж. Западная традиция права: эпоха формирования / пер. с англ. 2-е изд. М.: Изд-во МГУ: Издательская группа ИНФРА-М-НОРМА, 1998.

10. Вилкова Н.Г. Договорное право в международном обороте. М.: «Статут», 2002.

64 The Treaty of Lisbon. 2007 // OJ C 306, 17 December 2007 // URL: http://europa.eu/lisbon_treaty/ull_text/index_en.htm (дата обращения: 06.01.2013). 


\section{Международные отношения International Relations}

11. Вышинский А.Я., Лозовский С.А. Американо-британские соглашения 1940-1941 // Дипломатический словарь. М.: Государственное издательство политической литературы. 1948 // URL: http://dic.academic. ru/dic.nsf/dic_diplomatic/67 (дата обращения: 04.01.2013).

12. Глинкин А.Н. Соглашение по АЛКА: за год до финиша // Латинская Америка 2004. № 1. С. 4-21.

13. Гражданское и торговое право зарубежных стран: учеб. пособие / под общ. ред. В.В. Безбаха и В.К. Пучинского. М.: МЦФЭР, 2004.

14. Дупас Ж. Новые дилеммы государственности, управления и интеграции с точки зрения логики глобализации // Латинская Америка. 2001. № 6. С. 50-59.

15. Европейское сообщество: регулирование интеграционных процессов / отв. ред. М.М. Максимова, Ю.В. Шишков, Т. Паланкаи. М.: Наука, 1986.

16. Жидков О.А. Становление правовых систем в странах Латинской Америки // Государственно-правовые проблемы стран Латинской Америки. Сб. научных трудов. М.: Изд-во УДН, 1988. С. 6-31.

17. Ивлева Т.Н. Как бороться с финансовыми кризисами: три подхода // Латинская Америка. 2001. № 3. С. 4-13.

18. Казачкова 3.М. Государственное антимонопольное регулирование в России и США: сравнительно-правовое исследование: дис. ... д-ра юрид. наук. М., 2002.

19. Калачян К. Региональная экономическая интеграция как часть мирового процесса интеграции. М.: МАКС-Пресс, 2003.

20. Капустин А.Я. Международно-правовые проблемы латиноамериканской экономической интеграции: учеб. пособие. - М.: Изд-во УДН, 1986.

21. Кашкин С.Ю., Калиниченко П.А. Общий рынок. // Глобалистика: энциклопедия. — М., 2003.

22. Клаверен А.В. Латинская Америка на пути к открытому регионализму // Латинская Америка. - 1997. № 6. С. 4-15.

23. Комаров А.С., Бардина М.П., Шумилов В.М. Международное экономическое право: учеб.-методич. пособие. М.: ДЕКА-ВС, Государственный центральный музей музыкальной культуры им. М.И. Глинки, 1999.

24. Комкова Е.Г. Канада - США: на пути к таможенному союзу? // США - Канада. Экономика, политика, культура. 2004. № 5. С. 32-48.

25. Комкова Е.Г. Канада в процессах североамериканской экономической интеграции: теоретические и практические аспекты (на примере НАФТА): автореф. дис. ... д-ра экон. наук. М., 2011. 41 с.

26. Комкова Е.Г. Канада и НАФТА: экономические итоги десятилетия // США - Канада. Экономика, политика, культура. 2005. № 12. С. 3-24.

27. Комкова Е.Г. Этапы и особенности североамериканской интеграции // Канада и НАФТА: итоги и перспективы североамериканской экономической интеграции. РАН. Институт США и Канады, Российское общество изучения Канады. М.: Институт США и Канады РАН, 2005.

28. Лавут А.А. Андская группа: от застоя к модернизации? // Латинская Америка. 1997. № 3. С. 11-17.

29. Ложечко М.С. Страны-члены НАФТА и интеграционные процессы (проблемы и перспективы): дис. ... канд. экон. наук. М., 2000.

30. Материалы Круглого стола Института Латинской Америки «Восходящие страны-гиганты на мировой сцене XXI века» // Латинская Америка. № 6, 7. 2005. С. 4-18.

31. Моисеев А. Демократия дала сбой в Парагвае. // Международная жизнь. 16/07/2012 // URL: http://ref. interaffairs.ru/read.php?item=8610 (дата обращения: 09.01.2013).

32. Монтескье Ш. О духе законов. Кн.1. Гл. ІІІ // Монтескье Ш. Избранные произведения. М.: Гос. изд-во политич. литературы, 1995.

33. Позднеева Л.В. Канада в годы Второй мировой войны. М.: Наука, 1986.

34. Право Европейского Союза: правовое регулирование торгового оборота: учеб. пособие / под ред. В.В. Безбаха, А.Я. Капустина, В.К. Пучинского. М.: ЗЕРЦАЛО, 2000.

35. Право Европейского Союза: учебник для вузов / под ред. С. Ю. Кашкина. М.: Юристъ, 2002.

36. Репортаж с совместной пресс-конференции послов Республики Кубы и Боливарианской Республики Венесуэла в Российской Федерации Хорхе Марти Мартинеса и Алексиса Наварро Рохаса, которая была посвящена проблемам интеграции в Латинской Америке. 5 июля 2006 г. // Электронный выпуск «Экономической и философской газеты» // URL: http://www.eifgaz.ru/app-262006.htm (дата обращения: 31.07.10).

37. Романова 3.И. Региональная интеграция - новые вызовы // Латинская Америка. 2003. № 8. С. 4-16.

38. Романова 3.И. Финансовый рынок в условиях глобализации // Латинская Америка. 2000. № 9. С. 4-16.

39. Топорнин Б.Н. Европейское право: учебник. М.: Юристъ, 2001. 


\section{Региональные конфигурации международных отношений /}

Regional configuration of international relations

40. Фултонская речь У. Черчилля // URL: http://www.coldwar.ru/churchill/fulton.php (дата обращения: 06.01.2013).

41. Экономика: учебник / под ред. А.И. Архипова, А.Н. Нестеренко, А.К. Большакова. М.: «ПРОСПЕКТ», 1999.

42. Acuerdo entre el Presidente de la República Bolivariana de Venezuela y el Presidente del Consejo de Estado de Cuba, para la aplicación de la Alternativa Bolivariana para las Américas. 14/12/2004. URL: http://www. alianzabolivariana.org/modules.php?name=Content\&pa=showpage\&pid=2079 (дата обращения: 31.07.10).

43. Ahora se obliga a Centroamérica y otros países a suscribir TLC bilaterales que los pueblos rechazamos. Fuertes reacciónes en toda América Latina frente a los TLC. 17/2/05. URL: www.revistapueblos.org/spip.php?article153 (дата обращения: 07.08.10).

44. Ante el estancamiento del TLC con EEUU, Colombia se asocia con Canadá y China. Viernes, 21 de Noviembre de 2008. // Reuters. URL: http://www.adnmundo.com/contenidos/econycom/estancamiento_tlc_eeuu_colombia_canada_china_apec_estados_unidos_congreso_uribe_ce_211108.html (дата обращения: 31.07.10).

45. Brzezinski Zb. Out of control. Global Turnout on the Eve of the 21 Century. N.Y.-Toronro, 1993. P. 221.

46. Carmona P. Objetivos y contenido de la integración regional: políticas de convergencia y efectos del ajuste. // Documentos de Trabajo Publicados por CEFIR, 1993. URL: http://www.cefir.org.uy/dt01doc.htm (дата обращения: 04.05.2005).

47. Clubbing together. // The Economist, November $22^{\text {nd }}-28^{\text {th }} 2003$. P. 13-14.

48. Cronologia do Mercosul (1985-1999): Centro Brasileño de Documentación y Estudios de Bacia do Prata (CEDEP), Universidad Federal de Río Grande do Sul (UFRGS) URL: www.cedep.ifch.ufrgs.br/Cronologiamercosul/cron_mercosul.doc (дата обращения: 31.07.10).

49. Dura respuesta del MERCOSUR a acusaciónes de EE.UU. // Diario HOY, 20 de noviembre del 2004.

50. Eduardo Arce. Polémica en torno a la firma del Protocolo de Montevideo en el Mercosur. // E`a. Periodico de Inter-pretacion y Analisys. Enero 11, 2012. URL: http://ea.com.py/polemica-en-torno-a-la-firma-del-protocolo-de-montevideo-en-el-mercosur/ (дата обращения: 09.01.2013).

51. EE.UU. acusa a MERCOSUR de trabar creación del ALCA. // Cadena Global/AP 19 de noviembre del 2004.

52. EE.UU. y Brasil difieren en temas relaciónados con el ALCA. // Prensa Latina, 27 de octubre del 2004.

53. Entró en vigencia el TLC Perú-EE.UU. 16 de Enero del 2009. URL: http://www.rpp.com.pe/2009-01-16-entroen-vigencia-el-tlc-Perú-ee-uu-noticia_157866.html (дата обращения: 07.08.10).

54. Flynn M. Brazil Increasingly Unenthusiastic about U.S. FTAA Proposals. Has Bush's "Century of the Americas" already come and gone? February 1, 2002 URL: http://www.cipamericas.org/archives/1171 (дата обращения: 31.07.10).

55. Flynn M. Bush and Lula: A Collision of Two Worlds, July 10, 2003. URL: http://www.cipamericas.org/archives/1155 (дата обращения: 31.07.10).

56. Gudynas E. El MERCOSUR ante el ALCA: Nuevas tensiones y nuevas opciones, 29 de octubre de 2003 // URL: http://www.cipamericas.org/archives/1126 (дата обращения: 31.07.10).

57. Hansen-Kuhn K. Free Trade Area of the Americas. December 1, 1996 // Foreign Policy In Focus, 6(12), 2001. URL: http://www.fpif.org/reports/free_trade_area_of_the_americas (дата обращения: 31.07.10).

58. Katz C. Alternativas al ALCA. MERCOSUR y ALCA: del fracaso a la sumisión. // Progreso Semanal, enero 2004. URL: http://www.diariomardeajo.com.ar/alternativasalalca.htm (дата обращения: 31.07.10).

59. MERCOSUR - Unión Europea. URL: http://www.sice.oas.org/tpd/mer_eu/mer_eu_e.asp (дата обращения: 31.07.10).

60. MERCOSUR/CMC/DEC. № 43/04: Atribución a la República del Ecuador de la condición de estado asociado del MERCOSUR. URL: http://www.mercosur.int/msweb/Normas/normas_web/Decisiones/ES/DEC043-004EstAsocEcuador-S_Acta2-04.PDF (дата обращения: 31.07.10).

61. MERCOSUR/CMC/DEC. № 44/04: Atribución a la República de Colombia de la condición de estado asociado del MERCOSUR. URL: http://www.mercosur.int/msweb/Normas/normas_web/Decisiones/ES/DEC044-004-EstAsocColCB4mbia-ES_Acta2-04.PDF (дата обращения: 31.07.10).

62. Mercosur: Commission approves EUR 4 million to support regional integration. Brussels, 12 March 2004. URL: http://europa.eu/rapid/pressReleasesAction.do?reference=IP/04/331\&format=HTML\&aged=0\&language=E N\&guiLanguage=en (дата обращения: 31.07.10).

63. Muirhead B.W. The Development of Postwar Canadian Trade Policy. The Failure of the Anglo-European Option. Montreal \& Kingston, London, Buffalo: McGill-Queen`s University Press, 1992. P. 179.

64. PeñaF.Does Mercosurhavefuture? May 2003.URL: http://www.felixpena.com.ar/index.php?contenido=wpapers (дата обращения: 31.07.10) 


\section{Международные отношения International Relations}

65. Peña F. Reflexiones sobre el Mercosur y su futuro, Septiembre 2002. URL: http://www.felixpena.com.ar/index. php?contenido=wpapers (дата обращения: 31.07.10).

66. Perú y Colombia reanudarían el diálogo por un TLC con la UE en enero de 2009. Jueves, 13 de Noviembre de 2008. // Andina. URL: http://www.adnmundo.com/contenidos/econycom/Perú_colombia_dialogo_tlc_ue_enero_2009_can_bolivia_morales_belaunde_ce_131108.html (дата обращения: 31.07.10).

67. Protocolo de Adhesión de la República Bolivariana de Venezuela al MERCOSUR. 4/07/2006. URL: http://www. mercosur.int/innovaportal/file/2485/1/2006_PROTOCOLO_ES_AdhesionVenezuela.pdf (дата обращения: 09.01.2013).

68. Protocolo de Adhesión del Estado Plurinacional de Bolivia al MERCOSUR. 7/12/2012. URL: http://www.mercosur. int/innovaportal/file/2485/1/protocolo_adhesion_bolivia_al_mercosur.pdf (дата обращения: 09.01.2013).

69. Protocolo de Montevideo sobre Compromiso con la Democracia en el MERCOSUR (Ushuaia II). 20/12/2012. URL: http://www.mercosur.int/innovaportal/file/2485/1/ushuaia_ii.pdf (дата обращения: 09.01.2013).

70. Rio Group not too enthusiastic about FTAA. // Mercopress, Saturday, 06 November URL: en.mercopress. com/2004/11/06/rio-group-not-too-enthusiastic-about-ftaa (дата обращения: 31.07.10).

71. Silvia E. Stamato. El futuro del Mercosur. Perspectivas. // Union Industrial de San Martin. 9 de Enero de 2013 // URL: http://www.uidgsm.com.ar/modules.php?name=News\&file=article\&sid=17 (дата обращения: 09.01.2013).

72. Single European Act (1986) // Official Journal L 169 of 29 June 1987.

73. The Treaty of Lisbon. 2007 // OJ C 306, 17 December 2007. URL: http://europa.eu/lisbon_treaty/ull_text/ index_en.htm (дата обращения: 06.01.2013).

74. Tratado de Montevideo de 1980. URL: http://www.aladi.org/nsfaladi/juridica.nsf/tratadoweb/tm80 (дата обращения: 06.01.2013).

75. Treaty of Amsterdam amending the Treaty on European Union, the Treaties establishing the European Communities and related acts // Official Journal C 340, 10 November 1997.

76. Treaty on European Union (1992). // Official Journal C 191 of 29 July 1992.

77. Venezuela se incorporó formalmente al Mercosur. 31 de julio de 2012. URL: http://www.lanacion.com. ar/1494926-todo-listo-para-que-venezuela-se-incorpore-al-mercosur (дата обращения: 09.01.2013).

\section{References (transliteration):}

1. 10 let Merkosur // Latinskaya Amerika. 2001. № 7. S. 19-38.

2. Aktualizaciya processa vzaimodeistviya stran BRIKS v ekonomike, politike, prave: Materialy Nauchnogo seminara. Moskva, 9 oktyabrya 2012 g. / otv. red. i sost. Belikova K.M. M.: Senat Press, 2012. 251 s.

3. Anners E. Istoriya evropeiskogo prava (per. so shved.) / In-t Evropy. M.: Nauka, 1994.

4. Bahin S.V. Ponyatie i mehanizmy mezhdunarodno-pravovogo sblizheniya pravovyh sistem. // Rossiiskii ezhegodnik mezhdunarodnogo prava / Rossiiskaya associaciya mezhdunarodnogo prava; Red. kol.: L.N. Galenskaya (gl. red.) i dr. SPb.: SKF «Rossiya - Neva», 2001.

5. Bezbah V.V., Belikova K.M. Chto zastavlyaet latinoamerikancev ob'edinyat'sya? Obrazovanie Yuzhnoamerikanskogo Obshego rynka i ego razvitie // Vneshnetorgovoe pravo. 2006. № 1(6). S. 8-12.

6. Belikova K.M. Na puti k edinomu rynku v Yuzhnoi Amerike: faktory integracii v ekonomike i prave. // Vestnik Rossiiskogo universiteta druzhby narodov. Seriya «Yuridicheskie nauki». 2005. № 1. S. 83-89.

7. Belikova K.M. Obshii rynok v Evrope: integraciya i differenciaciya // Mezhdunarodnoe publichnoe i chastnoe pravo. 2005. № 1 (22). S. 14-17.

8. Belikova K.M. Pravovoe regulirovanie torgovogo oborota i kodifikaciya chastnogo prava v stranah Latinskoi Ameriki: Monografiya. M.: Yusticinform 2010. S. 89-102 (480 s.)

9. BermanG.Dzh. Zapadnaya tradiciya prava: epoha formirovaniya / per. s angl. 2-e izd. M.: Izd-vo MGU: Izdatel'skaya gruppa INFRA-M-NORMA, 1998.

10. Vilkova N.G. Dogovornoe pravo v mezhdunarodnom oborote. M.: «Statut», 2002.

11. Vyshinskii A.Ya., Lozovskii S.A. Amerikano-britanskie soglasheniya 1940-1941 // Diplomaticheskii slovar'. M.: Gosudarstvennoe izdatel'stvo politicheskoi literatury. 1948 // URL: http://dic.academic.ru/dic.nsf/dic_diplomatic/67 (data obrasheniya: 04.01.2013)

12. Glinkin A.N. Soglashenie po ALKA: za god do finisha // Latinskaya Amerika. 2004. № 1. S. 4-21

13. Grazhdanskoe i torgovoe pravo zarubezhnyh stran: ucheb. posobie / pod obsh. red. V.V. Bezbaha i V.K. Puchinskogo. M.: MCFER, 2004. 


\section{Региональные конфигурации международных отношений / Regional configuration of international relations}

14. Dupas Zh. Novye dilemmy gosudarstvennosti, upravleniya i integracii s tochki zreniya logiki globalizacii // Latinskaya Amerika. 2001. № 6. S. 50-59

15. Evropeiskoe soobshestvo: regulirovanie integracionnyh processov / otv. red. M.M. Maksimova, Yu.V. Shishkov, T. Palankai. M.: Nauka, 1986.

16. Zhidkov O.A. Stanovlenie pravovyh sistem v stranah Latinskoi Ameriki // Gosudarstvenno-pravovye problemy stran Latinskoi Ameriki. Sb. nauchnyh trudov. - M.: Izd-vo UDN, 1988. S. 6-31.

17. Ivleva T.N. Kak borot’sya s finansovymi krizisami: tri podhoda // Latinskaya Amerika. 2001. № 3. S. 4-13.

18. Kazachkova Z.M. Gosudarstvennoe antimonopol'noe regulirovanie v Rossii i SShA: sravnitel'no-pravovoe issledovanie: dis. ... d-ra yurid. nauk. M., 2002.

19. Kalachyan K. Regional'naya ekonomicheskaya integraciya kak chast' mirovogo processa integracii. M.: MAKSPress, 2003.

20. Kapustin A.Ya. Mezhdunarodno-pravovye problemy latinoamerikanskoi ekonomicheskoi integracii: ucheb. posobie. M.: Izd-vo UDN, 1986.

21. Kashkin S.Yu., Kalinichenko P.A. Obshii rynok. // Globalistika: enciklopediya. M., 2003.

22. Klaveren A.V. Latinskaya Amerika na puti k otkrytomu regionalizmu // Latinskaya Amerika. 1997. № 6. S. 4-15.

23. Komarov A.S., Bardina M.P., Shumilov V.M. Mezhdunarodnoe ekonomicheskoe pravo: ucheb.-metodich. posobie. M.: DEKA-VS, Gosudarstvennyi central'nyi muzei muzykal'noi kul'tury im. M.I. Glinki, 1999.

24. Komkova E.G. Kanada - SShA: na puti k tamozhennomu soyuzu? // SShA - Kanada. Ekonomika, politika, kul'tura. 2004. № 5. S. 32-48.

25. Komkova E.G. Kanada v processah severoamerikanskoi ekonomicheskoi integracii: teoreticheskie i prakticheskie aspekty (na primere NAFTA): avtoref. dis. d-ra ekon. nauk. M., 2011. 41 s.

26. Komkova E.G. Kanada i NAFTA: ekonomicheskie itogi desyatiletiya // SShA - Kanada. Ekonomika, politika, kul'tura. 2005. № 12. S. 3-24.

27. Komkova E.G. Etapy i osobennosti severoamerikanskoi integracii // Kanada i NAFTA: itogi i perspektivy severoamerikanskoi ekonomicheskoi integracii. RAN. Institut SShA i Kanady, Rossiiskoe obshestvo izucheniya Kanady. M.: Institut SShA i Kanady RAN, 2005.

28. Lavut A.A. Andskaya gruppa: ot zastoya k modernizacii? // Latinskaya Amerika. 1997. № 3. S. 11-17.

29. Lozhechko M.S. Strany-chleny NAFTA i integracionnye processy (problemy i perspektivy): dis. ... kand. ekon. nauk. M., 2000.

30. Materialy Kruglogo stola Instituta Latinskoi Ameriki «Voshodyashie strany-giganty na mirovoi scene XXI veka» // Latinskaya Amerika. № 6, 7. 2005. S. 4-18.

31. Moiseev A. Demokratiya dala sboi v Paragvae // Mezhdunarodnaya zhizn'. 16/07/2012 // URL: http://ref.interaffairs.ru/read.php?item=8610 (data obrasheniya: 09.01.2013)

32. Montesk'e Sh. O duhe zakonov. Kn. 1. Gl. III // Montesk'e Sh. Izbrannye proizvedeniya. M.: Gos. izd-vo politich. literatury, 1995.

33. Pozdneeva L.V. Kanada v gody Vtoroi mirovoi voiny. M.: Nauka, 1986.

34. Pravo Evropeiskogo Soyuza: pravovoe regulirovanie torgovogo oborota: ucheb. posobie / pod red. V.V. Bezbaha, A.Ya. Kapustina, V.K. Puchinskogo. M.: ZERCALO, 2000.

35. Pravo Evropeiskogo Soyuza: uchebnik dlya vuzov / pod red. S.Yu. Kashkina. M.: Yurist', 2002.

36. Reportazh s sovmestnoi press-konferencii poslov Respubliki Kuby i Bolivarianskoi Respubliki Venesuela v Rossiiskoi Federacii Horhe Marti Martinesa i Aleksisa Navarro Rohasa, kotoraya byla posvyashena problemam integracii v Latinskoi Amerike. 5 iyulya 2006 g. // Elektronnyi vypusk «Ekonomicheskoi i filosofskoi gazety» // URL: http://www.eifgaz.ru/app-262006.htm (data obrasheniya: 31.07.10)

37. Romanova Z.I. Regional'naya integraciya — novye vyzovy // Latinskaya Amerika. 2003. № 8. S. 4-16.

38. Romanova Z.I. Finansovyi rynok v usloviyah globalizacii // Latinskaya Amerika. 2000. № 9. S. 4-16

39. Topornin B.N. Evropeiskoe pravo: uchebnik. M.: Yurist', 2001.

40. Fultonskaya rech' U. Cherchillya // URL: http://www.coldwar.ru/churchill/fulton.php (data obrasheniya: 06.01.2013)

41. Ekonomika: uchebnik / pod red. A.I. Arhipova, A.N. Nesterenko, A.K. Bol'shakova. M.: «PROSPEKT», 1999. 